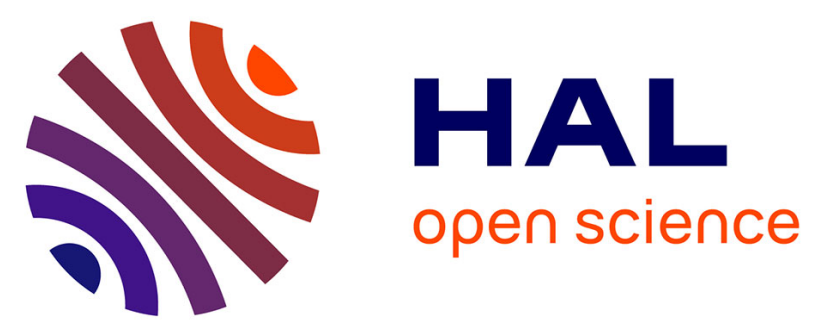

\title{
A fluorescent AND logic gate based on a ferrocene-naphthalimide-piperazine format responsive to acidity and oxidizability
}

Jake C Spiteri, Alex D Johnson, Sergey Denisov, Gediminas Jonusauskas, Nathan Mcclenaghan, David C Magri

\section{To cite this version:}

Jake C Spiteri, Alex D Johnson, Sergey Denisov, Gediminas Jonusauskas, Nathan Mcclenaghan, et al.. A fluorescent AND logic gate based on a ferrocene-naphthalimide-piperazine format responsive to acidity and oxidizability. Dyes and Pigments, 2018, 157, pp.278-283. 10.1016/j.dyepig.2018.04.060 . hal-01848447

\section{HAL Id: hal-01848447 \\ https://hal.science/hal-01848447}

Submitted on 24 Jul 2018

HAL is a multi-disciplinary open access archive for the deposit and dissemination of scientific research documents, whether they are published or not. The documents may come from teaching and research institutions in France or abroad, or from public or private research centers.
L'archive ouverte pluridisciplinaire HAL, est destinée au dépôt et à la diffusion de documents scientifiques de niveau recherche, publiés ou non, émanant des établissements d'enseignement et de recherche français ou étrangers, des laboratoires publics ou privés.

\section{(1)(1) $\$(0)$}

Distributed under a Creative Commons Attribution - NonCommercial - ShareAlikel 4.0 


\title{
A fluorescent AND logic gate based on a ferrocene-naphthalimide-piperazine format responsive to acidity and oxidizability
}

\author{
Jake C. Spiteri ${ }^{\mathrm{a}}$, Alex D. Johnson ${ }^{\mathrm{a}}$, Sergey A. Denisov ${ }^{\mathrm{b}}$, Gediminas Jonusauskas ${ }^{\mathrm{c}}$, \\ Nathan D. McClenaghan ${ }^{\mathrm{b}}$, David C. Magri ${ }^{\mathrm{a}, *}$ \\ a Department of Chemistry, Faculty of Science, University of Malta, Msida, MSD 2080, Malta \\ ${ }^{\mathrm{b}}$ Institut des Sciences Moléculaires, CNRS UMR 5255, University of Bordeaux, 33405 Talence, France \\ ${ }^{\mathrm{c}}$ Laboratoire Ondes et Matière d'Aquitaine, CNRS UMR 5798, University of Bordeaux, 33405 Talence, France
}

\section{A R T I C L E I N F O}

\section{Keywords:}

Naphthalimide

Ferrocene

Photoinduced electron transfer

Pourbaix sensor

Molecular logic gate

Fluorescence

\begin{abstract}
A B S T R A C T
A novel fluorescent molecular logic gate $\mathbf{1}$ is demonstrated as a two-input AND logic gate for the detection of acidity and oxidizability. Designed according to an electron-donor-spacer-fluorophore-spacer-receptor' format, the modules are represented by ferrocene as the electron donor, 1,8-naphthalimide as the fluorophore and piperazine as the proton receptor. In the presence of elevated concentrations of $\mathrm{H}^{+}$and $\mathrm{Fe}^{3+}$, the molecule switches 'on' emitting at $\lambda_{\max }=530 \mathrm{~nm}$ with $\Phi_{\mathrm{f}}=0.060$ at $10^{-4} \mathrm{M} \mathrm{H}^{+}$and $50 \mu \mathrm{M} \mathrm{Fe}{ }^{3+}$. The $\mathrm{H}^{+}$binding and apparent $\mathrm{Fe}^{3+}$ binding constants determined by fluorimetric titrations in 1:1 $(v / v)$ methanol/water are $\log \beta_{\mathrm{H}+}=8.1$ and $\log \beta_{\mathrm{Fe} 3+}=4.7$. Modulation of the fluorescence output results from controlling competing photoinduced electron transfer (PET) at the ferrocene end and internal charge transfer (ICT) at the piperazine end. Time-resolved fluorescence spectroscopy reveals a single fluorescent lifetime of $5.8 \mathrm{~ns}$, while from absorption transient spectroscopy a remarkable fast decay signal $<2$ ps is observed. Comparison is made with methylpiperazine 2 and piperazine fluorescent $\mathrm{pH}$ indicator $\mathbf{3}$ as model compounds.
\end{abstract}

\section{Introduction}

Many chemical and biological phenomena are dependent on $\mathrm{pH}$ and redox potential including corrosion [1], geochemistry [2], clinical chemistry [3] and anticancer treatments [4]. In recent years there has been a tremendous effort focused exclusively on $\mathrm{pH}$ sensing [5], notably for intracellular fluorescence imaging applications [6]. In contrast, the field of luminescent redox indicators has not received as much attention and offers much opportunity for future development [7]. Indeed, de spite there being numerous molecular probes for specifically mon itoring the $\mathrm{pH}$ or the redox environment in living cells, there are no commercially available probes that simultaneously probe $\mathrm{pH}$ and $\mathrm{pE}$ in living cells [8]. Molecular probes that are able to detect and measure high concentrations of both protons and redox active oxidants could be valuable diagnostic imaging tools for diseases such as cancer [9].

We are interested in engineering molecular logic gates that detect acidic and oxidizing conditions by emitting an optical signal. We deemed this class of smart molecule 'Pourbaix sensors' in honour of Marcel Pourbaix, the father of corrosion science [1]. Molecular logic gates specifically combining acid base and redox equilibria are still rather rare $[10,11]$. Our first proof of concept prototypes were based on the hydrophobic fluorophore anthracene [12 14]. We subsequently designed 'Pourbaix sensors' with the non symmetrical naphthalimide fluorophore $[15,16]$. Naphthalimides are routinely used in molecular probe design due to their facile synthetic pathways, compatible water solubility and emission at longer wavelengths, among other favourable properties [17,18]. More specifically, chemosensors and molecular logic gates combining a naphthalimide fluorophore with a piperazine receptor represent a successful design strategy for many applications [19 23]. We and others who are interested in redox responsive optical molecules have employed the ferrocene naphthalimide piperazine platform to demonstrate proof of concepts of three input INHIBIT [24] and three input INHIBIT AND OR [25] combinatorial logic gate arrays. Other research groups have demonstrated $\mathrm{pH} /$ redox multi stimuli ma terials [26], nanogels [27], polymers [28], film materials [29] and degradable micelles [30].

Herein we report the synthesis and characterisation of a naphtha limide based logic gate 1 (Scheme 1) with an electron donor spacer fluorophore spacer receptor format [15]. 'Pourbaix sensor' 1 consists of ferrocene (electron donor) connected to 1,8 naphthalimide (fluor ophore) by a methylene spacer, which is connected to piperazine (proton receptor/electron donor). The molecule is demonstrated as an

\footnotetext{
* Corresponding author.

E-mail addresses: gediminas.jonusauskas@u-bordeaux.fr (G. Jonusauskas), nathan.mcclenaghan@u-bordeaux.fr (N.D. McClenaghan), david.magri@um.edu.mt (D.C. Magri).
} 


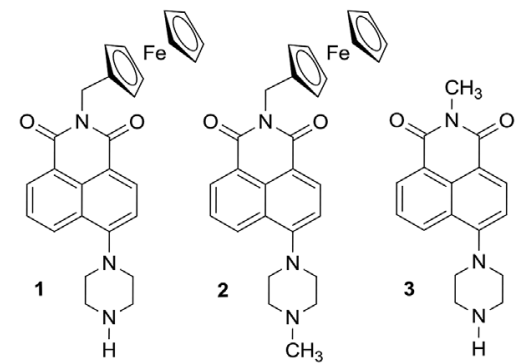

Scheme 1. The 1,8-naphthalimide-based fluorescent logic gates 1-3.

AND logic gate responsive to protons and $\mathrm{Fe}^{3+}$ as the oxidant in aqu eous methanol. Previously reported methylpiperazine prototype 2 and piperazine fluorescent $\mathrm{pH}$ indicator $\mathbf{3}$ are studied as model compounds (Scheme 1).

\section{Experimental}

\subsection{Materials}

$N$ Ferrocenyl 4 bromo 1,8 naphthalimide was synthesized as reported (Scheme S1) [15]. Piperazine ( $99 \%$, Alfa Aesar) was used as received. Tetrabutylammonium hydroxide ( $25 \mathrm{wt} \%$ in $\mathrm{H}_{2} \mathrm{O}$ ), iron(III) sulfate pen tahydrate (97\%) and methanesulfonic acid ( $\geq 99.5 \%)$ were obtained from Sigma Aldrich and used as received. Solvents were HPLC grade.

\subsection{Instrumentation}

Melting points were recorded with a Stuart SMP40 automatic melting point apparatus. ${ }^{1} \mathrm{H}$ and ${ }^{13} \mathrm{C}$ NMR spectra were recorded on a Bruker Avance III HD NMR spectrometer at $500.13 \mathrm{MHz}$ and $125.76 \mathrm{MHz}$, respectively. Chemical shifts are reported in ppm down field from TMS at $\delta=0.00 \mathrm{ppm}$ and $\delta=77.00 \mathrm{ppm}$ for ${ }^{1} \mathrm{H}$ and ${ }^{13} \mathrm{C}$ NMR. Infra red spectra were recorded using a Shimadzu IR Affinity 1 spectrophotometer calibrated against $1601 \mathrm{~cm}^{-1}$ polystyrene absorp tion peak as $\mathrm{KBr}$ disks. HRMS was performed by ES ToF technique and performed by Medac Ltd (UK). UV visible absorption spectra were obtained on a Jasco V 650 spectrophotometer. Fluorescence spectra were obtained on a Jasco FP 8300 spectrofluorimeter. Experiments were performed at room temperature $20^{\circ} \mathrm{C}$ in $10 \mathrm{~mm}$ quartz cuvettes. The time resolved luminescence set up was previously described [16]. $\mathrm{pH}$ measurements were recorded with a Hanna Instruments $\mathrm{pH} 210$ microprocessor meter with a $\mathrm{HI} 1131$ electrode calibrated at $\mathrm{pH} 4.00$ and $\mathrm{pH} 7.00$.

\subsection{Synthesis}

Reactions were carried out in round bottom flasks $(50 \mathrm{~mL}, 100 \mathrm{~mL}$ or $250 \mathrm{~mL}$ ) partially immersed in an oil bath and heated using on a IKA C MAG HS 7 hotplate fitted with an IKA ETS D5 temperature probe. Silica gel 60 (70 230 mesh, Fluka Analytical) and silica coated alumi nium foil (silica gel matrix with fluorescent indicator $254 \mathrm{~nm}$, Fluka Analytical) were used for column and thin layer chromatography, re spectively.

\subsection{1. $N$ Ferrocenylmethyl 4 piperazine 1,8 naphthalimide 1}

$N$ Ferrocenyl 4 bromo 1,8 naphthalimide $(0.199 \mathrm{~g}, \quad 0.420 \mathrm{mmol})$ and piperazine $(0.897 \mathrm{~g}, 10.4 \mathrm{mmol})$ were dissolved in $25 \mathrm{~mL}$ of DMF and refluxed for $2 \mathrm{~h}$. The reaction was diluted with $50 \mathrm{~mL}$ water and extracted with $\mathrm{CH}_{2} \mathrm{Cl}_{2}(3 \times 30 \mathrm{~mL})$, dried over anhydrous $\mathrm{MgSO}_{4}$, fil tered and the solvent removed in vacuo. The product was purified by column chromatography on silica gel eluted with $1: 1(v / v) \mathrm{CH}_{2} \mathrm{Cl}_{2}$ / $\mathrm{MeOH}$ and obtained as a yellow solid in $31 \%$ yield. $R_{\mathrm{f}}=0.50(20: 1(\mathrm{v} /$ v) $\left.\mathrm{CH}_{2} \mathrm{Cl}_{2} / \mathrm{MeOH}\right)$; m.p. $=132135^{\circ} \mathrm{C} ;{ }^{1} \mathrm{H} \mathrm{NMR}\left(\mathrm{CDCl}_{3}, 500 \mathrm{MHz}\right.$, ppm): $\delta 8.56$ (dd, $1 \mathrm{H}, J=7.3 \mathrm{~Hz}, 0.9, \operatorname{Ar} H$ ), $8.50(\mathrm{~d}, 1 \mathrm{H}, J=8.1 \mathrm{~Hz}$, Ar $H$ ), 8.38 (dd, $1 \mathrm{H}, J=8.5,0.9 \mathrm{~Hz}, \operatorname{Ar} H), 7.66$ (dd, $1 \mathrm{H}, J=7.9$, $0.9 \mathrm{~Hz}, \operatorname{Ar} H), 7.19$ (d, $1 \mathrm{H}, J=8.1 \mathrm{~Hz}, \operatorname{Ar} H), 5.11$ (s, $2 \mathrm{H},-\mathrm{CH}_{2}$ spacer), 4.50 (t, $2 \mathrm{H}, J=1.8 \mathrm{~Hz}, \mathrm{Cp}$ ), 4.20 (s, 5H, Cp), 4.06 (t, $2 \mathrm{H}$, $J=1.8 \mathrm{~Hz}, \mathrm{Cp}), 3.22\left(\mathrm{~m}, 4 \mathrm{H},-\mathrm{N}\left(\mathrm{CH}_{2} \mathrm{CH}_{2}\right)_{2} \mathrm{NH}\right), 3.20(\mathrm{~m}, 4 \mathrm{H},-\mathrm{N}$ $\left.\left(\mathrm{CH}_{2} \mathrm{CH}_{2}\right)_{2} \mathrm{NH}\right) ;{ }^{13} \mathrm{C} \mathrm{NMR}\left(\mathrm{CDCl}_{3}, 126 \mathrm{MHz}, \mathrm{ppm}\right): \delta 164.2,163.8$, 156.2, 132.6, 131.2, 130.2, 129.9, 126.2, 125.6, 123.4, 116.9, 115.0, 83.4, 70.4, 68.6, 68.0, 54.2, 46.1, 39.1; IR $\left(\mathrm{KBr}, \mathrm{cm}^{-1}\right): 3416(\mathrm{~N} \mathrm{H})$, 3092( $=$ C H), 2951 ( C H), 1690( $\mathrm{C}=\mathrm{O}), 1659(\mathrm{C}=\mathrm{O}), 1587,1516$, 1418, 1383, 1371, 1331, 1240, 1175, 1134, 1105, 1022, 827, 785; HRMS (ES ToF): Calculated $\mathrm{C}_{27} \mathrm{H}_{25} \mathrm{~N}_{3} \mathrm{O}_{2} \mathrm{Fe}[\mathrm{M}]^{+}$479.1296, found 479.1288.

\subsection{Spectroscopic measurements}

Solutions of 13 were prepared in 1:1 $(v / v)$ methanol/water with an absorbance of 0.1 . The excitation and emission slits were set at $2.5 \mathrm{~nm}$ and $5.0 \mathrm{~nm}$, respectively, with a scan rate of $200 \mathrm{~nm} \mathrm{~min}^{-1}$ and emis sion range of $400650 \mathrm{~nm}$. The acid dissociation constants $\left(\mathrm{p} \beta_{\mathrm{H}+}\right)$ were determined from fluorescence intensity $\mathrm{pH}$ plots and fitted to a line arized Henderson Hasselbalch equation adapted for spectroscopic measurements eq. (1) [31]:

$\log \left(\frac{I_{\mathrm{F}_{\max }}-I}{I-I_{\mathrm{F}_{\min }}}\right)=\mathrm{pH}-\mathrm{p} \beta_{H^{+}}$

$\mathrm{Fe}^{3+}$ titrations were performed in acidified 1:1 $(v / v)$ methanol/ water to prevent the formation of insoluble iron hydroxides. Known aliquots of $\mathrm{Fe}^{3+}$ were added by micropipette. A modified Henderson Hasselbalch equation was employed for determining the apparent $\mathrm{Fe}^{3+}$ binding constant $\left(\mathrm{p} \beta_{\mathrm{Fe}}{ }^{3+}\right)$ according to eq. (2):

$\log \left(\frac{I_{\mathrm{F}_{\max }}-I}{I-I_{\mathrm{F}_{\min }}}\right)=-\log \left[\mathrm{Fe}^{3+}\right]-\mathrm{p} \beta_{F e^{3+}}$

The molar extinction coefficients $(\varepsilon)$ were determined according to the Beer Lambert Law eq. (3) where $A$ is the absorbance, $c$ is the con centration and $l$ is the cuvette path length. The relative fluorescence quantum yields $\left(\Phi_{\mathrm{f}}\right)$ were determined by eq. (4) from the area under the fluorescence spectra $(I)$, the absorbance at the excited wavelength $(A)$ and the solvent refractive index $(\eta)$. Reference values are denoted by the subscript 'ref'. Anthracene dissolved in ethanol (refractive index $1.36)$ with a $\Phi_{\text {ref }}$ of 0.27 was used as the standard [32].

$A=\varepsilon l c$

$\Phi_{\mathrm{f}}=\Phi_{\text {ref }}\left(\frac{I}{I_{\text {ref }}}\right)\left(\frac{A_{\text {ref }}}{A}\right)\left(\frac{\eta^{2}}{\eta_{\text {ref }}^{2}}\right)$

\section{Results and discussion}

\subsection{Synthesis and characterisation}

2 Ferrocenylmethyl 6 (piperazin $1 \mathrm{yl}$ ) $1 \mathrm{H}$ benzo[de]isoquinoline $1,3(2 \mathrm{H})$ dione 1 was synthesized from $N$ ferrocenyl 4 bromo 1,8 naphthalimide reacted with piperazine in $31 \%$ yield after purification (Scheme S1). We fully characterised 1 by ${ }^{1} \mathrm{H}$ and ${ }^{13} \mathrm{C}$ NMR, FTIR and HRMS (Figs. S1 S4). Compound 1 was previously reported from the synthesis of 6 (piperazin 1 yl)benzo[de]isochromene 1,3 dione with ferrocenylmethylamine in $16 \%$ yield [24]. In this previous work, 1 was used as a synthetic intermediate and not satisfactorily characterised. We note that ${ }^{13} \mathrm{C}$ NMR resonances at $c a .39 .1 \mathrm{ppm}$ and $130.2 \mathrm{ppm}$ were not reported, and it is unclear whether the reported ${ }^{1} \mathrm{H}$ NMR resonances are for $\mathrm{CDCl}_{3}$ or DMSO $d_{6}$. From the FTIR spectrum one can clearly identify the diagnostic broad secondary $\mathrm{N} \mathrm{H}$ stretching vibration at $3416 \mathrm{~cm}^{-1}$ and the intense carbonyl stretches at $1690 \mathrm{~cm}^{-1}$ and $1659 \mathrm{~cm}^{-1}$. 
Table 1

Comparison of the photophysical data of 1-3 in 1:1 $(v / v) \mathrm{MeOH} / \mathrm{H}_{2} \mathrm{O}$. ${ }^{\text {a }}$

\begin{tabular}{|c|c|c|c|}
\hline & 1 & 2 & 3 \\
\hline$\lambda_{\mathrm{Abs}(\mathrm{pH} 10)} / \mathrm{nm}(\log \varepsilon)$ & 405 (3.95) & $408(3.91)$ & 407 (3.84) \\
\hline$\lambda_{\mathrm{Abs}(\mathrm{pH} 4)} / \mathrm{nm}(\log \varepsilon)$ & $386(4.01)$ & 385 (3.89) & $384(3.94)$ \\
\hline$\left.\lambda_{\mathrm{Abs}(\mathrm{pH} 10}+50 \mu \mathrm{M} \mathrm{Fe}^{3+}\right) / \mathrm{nm}(\log \varepsilon)$ & $408(4.08)$ & $401(4.03)$ & - \\
\hline$\left.\lambda_{\mathrm{Abs}(\mathrm{pH}} 4+50 \mu \mathrm{M} \mathrm{Fe}^{3+}\right) / \mathrm{nm}(\log \varepsilon)$ & 385 (4.16) & $381(4.05)$ & - \\
\hline$\lambda_{\text {iso }} / \mathrm{nm}$ & 400 & 400 & 401 \\
\hline$\left.\lambda_{\mathrm{f}(\mathrm{pH} 4}+50 \mu \mathrm{M} \mathrm{Fe}^{3+}\right) / \mathrm{nm}$ & 530 & 528 & 528 \\
\hline$\left.\Delta \lambda_{(\mathrm{pH} 4}+50 \mu \mathrm{M} \mathrm{Fe}^{3+}\right) / \mathrm{nm}$ & 130 & 128 & 127 \\
\hline $\mathrm{p} \beta_{\mathrm{H}^{+*}}{ }^{\mathrm{e}}$ & 8.1 & 7.7 & 8.1 \\
\hline $\mathrm{p} \beta_{\mathrm{H}^{+*}}{ }^{\mathrm{f}}$ & 8.0 & 7.2 & - \\
\hline $\mathrm{p} \beta_{\mathrm{Fe}^{3+}}{ }^{\mathrm{g}}$ & 4.7 & 4.6 & - \\
\hline$\Phi_{\text {f (acid) }}{ }^{h}$ & 0.060 & 0.086 & 0.20 \\
\hline $\mathrm{FE}$ & 6 & 13 & 138 \\
\hline$\tau / \mathrm{ns}^{\mathrm{i}}$ & 5.8 & 7.3 & - \\
\hline
\end{tabular}

a Sensors concentration $\sim 5-10 \mu \mathrm{M}$.

b $\mathrm{pH}$ adjusted with $\mathrm{NaOH}$ or $\left(\mathrm{C}_{4} \mathrm{H}_{9}\right)_{4} \mathrm{NOH}$ and $\mathrm{CH}_{3} \mathrm{SO}_{3} \mathrm{H}$ solutions.

c Estimated errors for $\mathrm{p} \beta_{\mathrm{H}^{+}}, \mathrm{p} \beta_{\mathrm{Fe}^{3+}}$ and $\log \varepsilon$ are $\pm 0.2, \pm 0.2$ and \pm 0.3 , respectively. Duplicate measurements.

${ }^{\mathrm{d}}$ Molar absorptivity $\varepsilon$ in $\mathrm{L} \mathrm{mol}^{-1} \mathrm{~cm}^{-1}$

e Determined by $\log \left(\left(\begin{array}{lll}I_{\max } & I\end{array}\right) /\left(\begin{array}{ll}I & I_{\min }\end{array}\right)\right)=\log \left[\mathrm{H}^{+}\right]+\log \beta_{\mathrm{H}^{+}}$in absence of $\mathrm{Fe}^{3+}$.

${ }^{\mathrm{f}}$ In presence of $50 \mu \mathrm{M} \mathrm{Fe} \mathrm{F}^{3+}$.

$\mathrm{g}$ Determined by $\log \left(\left(\begin{array}{lll}I_{\max } & I\end{array}\right) /\left(\begin{array}{ll}I & I_{\min }\end{array}\right)\right)=\log \left[\mathrm{Fe}^{3+}\right]+\log \beta_{\mathrm{Fe}^{3+}}$.

h At $10^{-4} \mathrm{M} \mathrm{H}^{+}$and $50 \mu \mathrm{M} \mathrm{Fe}^{3+}$ in case of 1 and 2 .

${ }^{\mathrm{i}}$ Fluorescence lifetimes in presence of $10^{-4} \mathrm{M} \mathrm{H}^{+}$and $50 \mu \mathrm{M} \mathrm{Fe}^{3+}$.

\subsection{Photophysics of 1 and 2}

The UV visible absorption spectra of $\mathbf{1}$ and $\mathbf{2}$ in 1:1 $(v / v)$ methanol/ water display broad bands between 300 and $550 \mathrm{~nm}$ (Fig. S5). The peak maxima in acidic and basic solutions are situated at $386 \mathrm{~nm}$ and $405 \mathrm{~nm}$, respectively, with an isosbestic point at $400 \mathrm{~nm}$. A complete titration set of spectra are shown between $\mathrm{pH} 5$ and $\mathrm{pH} 10$ (Figs. S5a and e). The $\varepsilon$ values of $8000 \mathrm{~L} \mathrm{~mol}^{-1} \mathrm{~cm}^{-1}$ and $10000 \mathrm{~L} \mathrm{~mol}^{-1} \mathrm{~cm}^{-1}$ in acid and base, respectively, correspond to $\pi \rightarrow \pi^{*}$ electronic transitions within the naphthalimide fluorophore. The $\mathrm{pH}$ induced $20 \mathrm{~nm}$ hypso chromic shift in acidic solution is characteristic of an ICT mechanism associated with a less stable Franck Condon excited state. This is at least partly attributed to the piperazine group, which directly interferes with the naphthalimide $\pi$ conjugation due to a 'pre twisted' ICT in the ground state [33]. Similar photophysical characteristics were observed with 2 (Fig. S6a) [15] as summarised in Table 1.

The absorbance spectra of $\mathbf{1}$ under the four input conditions for AND logic are shown in Fig. 1 . The $\lambda_{\max }$ is observed to decrease with in creasing proton concentration. Upon addition of $50 \mu \mathrm{M} \mathrm{Fe}^{3+}$ a slight increase is observed in the absorbance. A higher concentration of $\mathrm{Fe}^{3+}$ does result in a greater fluorescence emission; however, this increases the possibility of an inner filter effect.

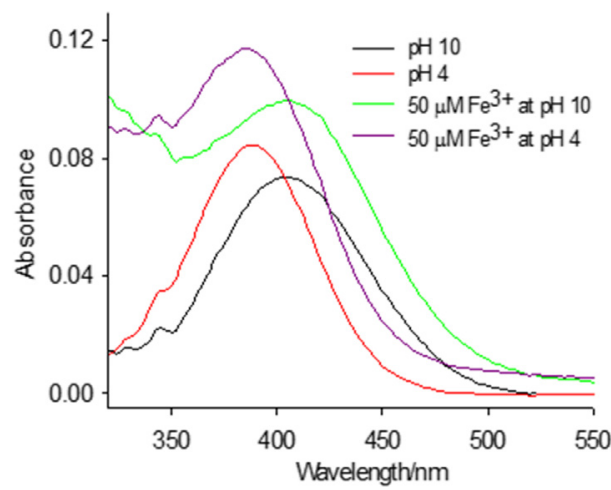

Fig. 1. UV-visible absorption spectra of $8.2 \mu \mathrm{M} 1$ in $1: 1(v / v) \mathrm{MeOH} / \mathrm{H}_{2} \mathrm{O}$ at four different input conditions of $\mathrm{H}^{+}$and $\mathrm{Fe}^{3+}$.

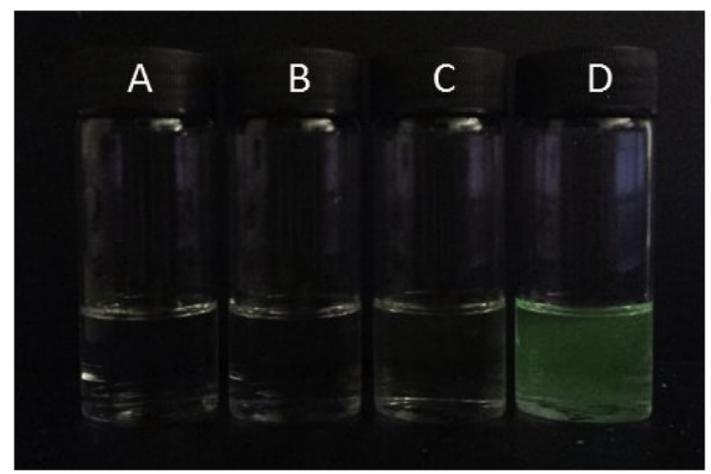

Fig. 2. Irradiation of $10^{-5} \mathrm{M} 1$ with UV light ( $365 \mathrm{~nm}$ ) under AND logic conditions in 1:1 $(v / v) \mathrm{MeOH} / \mathrm{H}_{2} \mathrm{O}$ : (A) $10^{-10} \mathrm{M} \mathrm{H}^{+}$, (B) $10^{-4} \mathrm{M} \mathrm{H}^{+}$(C) $10^{-10} \mathrm{M} \mathrm{H}^{+}$and $50 \mu \mathrm{M} \mathrm{Fe}^{3+}$ and (D) $10^{-4} \mathrm{M} \mathrm{H}^{+}$and $50 \mu \mathrm{M} \mathrm{Fe}^{3+}$.

Fluorescence emission spectra of $\mathbf{1}$ and $\mathbf{2}$ were obtained on excita tion at $400 \mathrm{~nm}$ providing broad emission spectra with a peak maximum at $530 \mathrm{~nm}$ (Fig. S5). Emission intensity $\mathrm{pH}$ profiles revealed sigmoidal shaped curves ranging three $\mathrm{pH}$ units (Figs. S5c and g). The calculated binding constants from the analysis of eq (1) by fluorimetric titration provided $\mathrm{p} \beta_{\mathrm{H}^{+}}$values of 8.1 and 7.7 for $\mathbf{1}$ and $\mathbf{2}$, respectively (Figs. S5c and g). $\mathrm{pH}$ titrations in the presence of $50 \mu \mathrm{M} \mathrm{Fe}^{3+}$ gave $\mathrm{p} \beta_{\mathrm{H}^{+}}$values of 8.0 and 7.2. (Fig. S6). Fluorimetric $\mathrm{Fe}^{3+}$ titrations at constant $\mathrm{pH} 4$ gave $\mathrm{p} \beta_{\mathrm{Fe}^{+}}$values of 4.7 and 4.6 for 1 and 2, respectively (Fig. S7).

The AND logic test of 1 in vials is qualitatively shown in Fig. 2. The truth table including $\Phi_{\mathrm{f}}$ are given in Table 2 . The 'vial test' of $\mathbf{1}$ displays a fluorescence output to the naked eye on irradiation with $365 \mathrm{~nm}$ light. The four possible conditions are (A) low $\mathrm{H}^{+}$and no oxidant, (B) high $\mathrm{H}^{+}$and no oxidant, (C) low $\mathrm{H}^{+}$and high oxidant and (D) high $\mathrm{H}^{+}$and high oxidant. A green fluorescence is only observed by the naked eye in the presence of $10^{-4} \mathrm{M} \mathrm{H}^{+}$and $50 \mu \mathrm{M} \mathrm{Fe}^{3+}$ (Fig. 2, vial D). In the other three cases, no fluorescence is observed by the naked eye, the maximum emission quantum yield being $\Phi_{\mathrm{f}} \leq 0.01$. Hence, compound 1 functions as a two input AND logic gate for acidity and oxidizability.

The fluorescence spectra of $\mathbf{1}$ associated with the four vials are overlaid in Fig. 3. The fluorescence output is significantly greater when both inputs are simultaneously present, whereas a low output is ob served when either one or both inputs are absent. The fluorescence enhancement for 1 is a 6 fold switching $\left(I_{\max }\left(50 \mu \mathrm{M} \mathrm{Fe} e^{3+}\right.\right.$ at $\left.\mathrm{pH} 4\right) / I_{\max }(\mathrm{pH}$ 4) ) whereas with 2 we observed up to a 13 fold enhancement [15]. The switching between the 'off' and 'on' states is slightly better for $\mathbf{2}$ than $\mathbf{1}$. Surprisingly, this difference is not due to the different proton receptors because the $\Phi_{\mathrm{f}}$ of 1 and 2 in the presence of $50 \mu \mathrm{M} \mathrm{Fe} \mathrm{F}^{3+}$ are rather

Table 2

Truth tables and fluorescence quantum yields of 1 and 2 in 1:1 $(v / v) \mathrm{MeOH} /$ $\mathrm{H}_{2} \mathrm{O}$ by steady-state fluorescence spectroscopy. ${ }^{\text {a d }}$

\begin{tabular}{lllll}
\hline Condition Label & $\begin{array}{l}\text { Input }_{1}{ }^{\mathrm{e}} \\
\left(\mathrm{H}^{+}\right)\end{array}$ & $\begin{array}{l}\mathrm{Input}_{2}{ }^{\mathrm{f}} \\
\left(\mathrm{Fe}^{3+}\right)\end{array}$ & $\begin{array}{l}\text { Output } 1^{\mathrm{g}} \\
\left(\Phi_{\mathrm{f}}\right)\end{array}$ & $\begin{array}{l}\text { Output } 2^{\mathrm{g}, \mathrm{h}} \\
\left(\Phi_{\mathrm{f}}\right)\end{array}$ \\
\hline $\mathrm{A}$ & 0 & 0 & 0 (low, 0.004) & $0($ low, 0.001) \\
$\mathrm{B}$ & 1 & 0 & 0 (low, 0.009) & $0($ low, 0.006) \\
$\mathrm{C}$ & 0 & 1 & 0 (low, 0.001) & 0 (low, 0.001) \\
$\mathrm{D}$ & 1 & 1 & 1 (high, 0.060) & 1 (high,0.086)
\end{tabular}

a Sensors concentration $\sim 5-10 \mu \mathrm{M}$.

b $\mathrm{pH}$ adjusted with $\mathrm{NaOH}$ or $\left(\mathrm{C}_{4} \mathrm{H}_{9}\right)_{4} \mathrm{NOH}$ and $\mathrm{CH}_{3} \mathrm{SO}_{3} \mathrm{H}$ solutions.

c 1 and 2 excited at $400 \mathrm{~nm}\left(\lambda_{\text {iso }}\right)$.

d Digital threshold limit set at $\Phi_{\mathrm{f}}>0.030$. Error \pm 0.008 and \pm 0.006 for 2 and 3 from average of three experiments.

e High input level $10^{-4} \mathrm{M} \mathrm{H}^{+}$. Low input level is $10^{-10} \mathrm{M} \mathrm{H}^{+}$.

${ }^{f}$ High input level $50 \mu \mathrm{M} \mathrm{Fe}{ }^{3+}$. Low input level no $\mathrm{Fe}^{3+}$ added.

$\mathrm{g}$ Relative $\Phi_{\mathrm{f}}$ measured with reference to anthracene in ethanol $\left(\Phi_{\mathrm{f}}=0.27\right)$ ref. [32].

h Published results ref. [16]. 


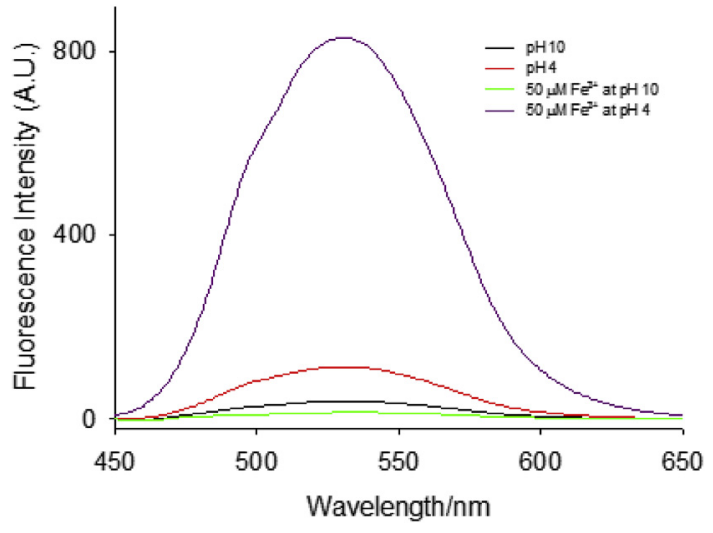

Fig. 3. Fluorescence spectra of $8.2 \mu \mathrm{M} 1$ in $1: 1(v / v) \mathrm{MeOH} / \mathrm{H}_{2} \mathrm{O}$ at four different input conditions of $\mathrm{H}^{+}$and $\mathrm{Fe}^{3+}\left(\lambda_{\text {ex }}=400 \mathrm{~nm}\right)$.

similar. It would be expected that the ICT efficiencies from the piper azine and methylpiperazine to the naphthalimide fluorophore would be nearly the same.

\subsection{Model piperazine compound $\mathbf{3}$}

Comparison to the naphthalimide piperazine model 3 provides in sight into the structural effect on the $\mathrm{pH}$ dependent fluorescence switching (See Table 2) [33]. A peak maximum is observed at $407 \mathrm{~nm}$ $\left(6900 \mathrm{~L} \mathrm{~mol}^{-1} \mathrm{~cm}^{-1}\right)$ in basic solution and $384 \mathrm{~nm}$ $\left(8700 \mathrm{~L} \mathrm{~mol}^{-1} \mathrm{~cm}^{-1}\right.$ ) in acidic solution with a clear isosbestic point at $401 \mathrm{~nm}$. These values are in good agreement with those of 1 confirming that the ferrocene moiety is electronically decoupled from the naph thalimide fluorophore by the methylene spacer. The $\Phi_{\mathrm{f}}$ of 3 is 0.20 when monoprotonated at $\mathrm{pH} 4$ and 0.002 when unprotonated at $\mathrm{pH} 10$, yielding a remarkable 138 fold fluorescence enhancement factor, which is due to the enhanced twisted piperazine ground state [33]. In contrast, the maximum $\Phi_{\mathrm{f}}$ of $\mathbf{1}$ is a more modest 0.060 even on protonation and oxidation, while in the absence of both input conditions the minimum $\Phi_{\mathrm{f}}$ is 0.004 at $\mathrm{pH} 10$. We observed a similar trend on comparing pyr azoline based fluorescent $\mathrm{pH}$ probes with pyrazoline ferrocene INH logic gates [34]. The cause of this limitation of fluorescent enhance ment is not fully understood. While protonation of the piperazine ni trogen atom results in a covalent bond, which implicates the electron lone pairs, oxidation of ferrocene by $\mathrm{Fe}^{3+}$ generates a radical cation intermediate. A recent comprehensive DFT study by us suggests there are localised deactivation pathways associated with ferrocene that may render a lower fluorescent quantum yield [35].

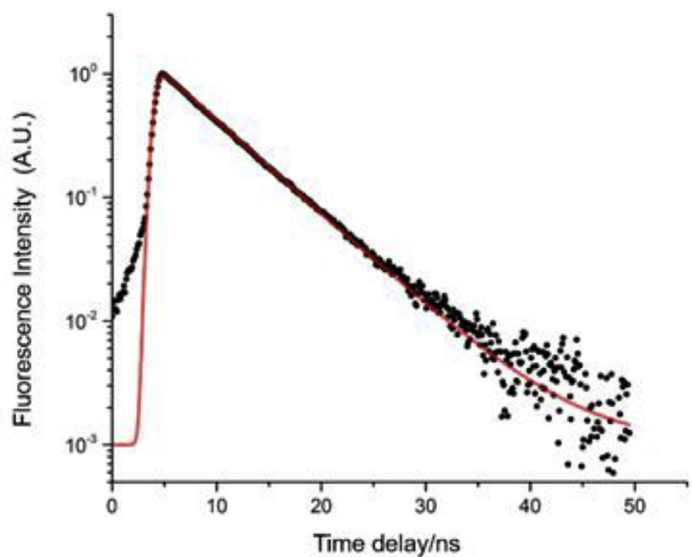

\subsection{Time resolved fluorescence spectroscopy}

A time resolved fluorescence study was undertaken to measure the fluorescence lifetimes of $\mathbf{1}$ at the four input conditions [16]. The fluorescence decay curve and 3D plot for the most fluorescent logic state are shown in Fig. 4. A complete set of fluorescence decay curves (a d) and 3D plots (e h) are available in the supporting information (Fig. S8). The experimental results highlight the efficient charge transfer processes between the piperazine and naphthalimide, and the ferrocene and naphthalimide fluorophore. For both 1 and 2, the fluorescence lifetime decay profiles are bi exponential in the absence of one or both inputs (Figs. S8a c). However, on addition of $\mathrm{H}^{+}$and $\mathrm{Fe}^{3+}$ a mono exponential decay profile is observed (Fig. 4, Fig. S8d). In the logic states 'A C', with no inputs or only one input, the long lifetime component $(\sim 90 \%)$ results from the intrinsic properties of the naph thalimide fluorophore. The fluorescence lifetimes of $\mathbf{1}$ and $\mathbf{2}$ (in the absence of at least one input) span 4.4 $5.5 \mathrm{~ns}$ and $6.67 .4 \mathrm{~ns}$, respec tively. The shorter lifetime component $(\sim 10 \%)$ corresponds to the suppressed fluorescence emission when one or both quenching me chanisms are operational: ICT from the proton receptor and/or PET from the ferrocene unit to the excited state fluorophore with a time constant less than $1 \mathrm{~ns}$. The addition of acid and oxidant deactivates the PET and ICT pathways and yields a single fluorescent lifetime compo nent (> 99\%). The fluorescence lifetimes are $7.3 \mathrm{~ns}$ for $\mathbf{2}$, whilst $\mathbf{1}$ has a slightly shorter lifetime of $5.8 \mathrm{~ns}$ in 1:1 $(v / v)$ methanol/water. It is plausible that the discrepancy originates from the positive inductive effect of the methyl group in $\mathbf{2}$, which better stabilises the protonated amine resulting in a longer lifetime in the excited state. The 3D surface plots (Figs. S8e h) provide similar information as the lifetime decay curve, but with the additional dimension of the emission wavelength. From these plots it is easy to appreciate how the fluorescence is re markably enhanced in the presence of both inputs $\mathrm{H}^{+}$and $\mathrm{Fe}^{3+}$ com pared to the other three input conditions.

\subsection{Femtosecond transient absorption spectroscopy}

Further insight into the photophysics of 1 was gained from femto second transient absorption studies. The transient map of $\mathbf{1}$ is shown in Fig. 5. After excitation ( $<1 \mathrm{ps)} \mathbf{1}$ experiences a significant charge density shift within the naphthalimide fluorophore due to the inherent ICT character. Ground state bleaching is observed at $420450 \mathrm{~nm}$ (red) and stimulated emission at $500650 \mathrm{~nm}$ (blue). We previously noted that the transient signal recovery rate of $\mathbf{2}$ was faster compared to a methylpiperazine model ( $\sim 50 \mathrm{ps})$ due to the faster excited state elec

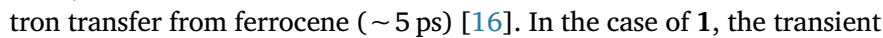
signal recovery rate is remarkable fast at $<2 \mathrm{ps}$. In the absence of either input, the excited state absorption has bi exponential decays of $270 \mathrm{fs}$

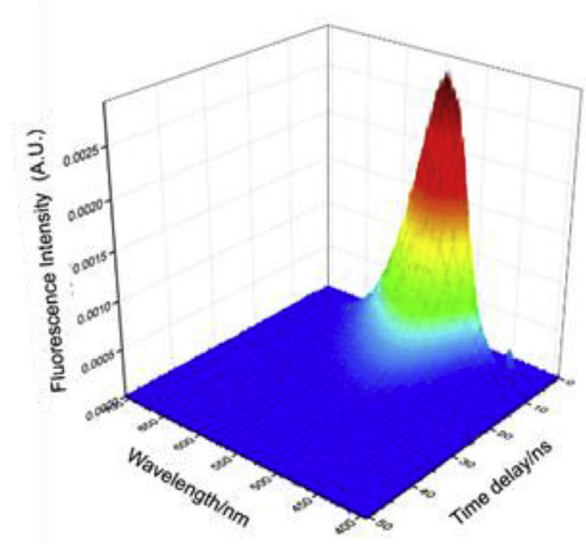

Fig. 4. Fluorescence decay curve and 3D surface plot of 1 in $1: 1(v / v) \mathrm{MeOH} / \mathrm{H}_{2} \mathrm{O}$ in presence of $10^{-4} \mathrm{MH}^{+}$and $50 \mu \mathrm{M} \mathrm{Fe} e^{3+}\left(\lambda_{\text {ex }}=400 \mathrm{~nm}\right)$. 


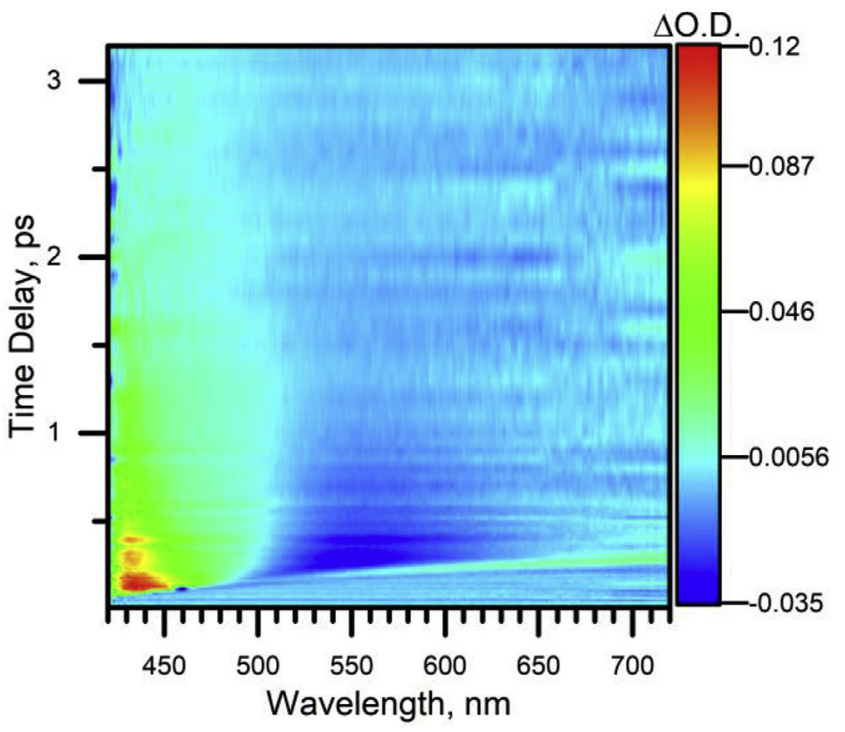

Fig. 5. Transient absorption map of $\mathbf{1}$ in acetonitrile in presence of $10^{-4} \mathrm{M} \mathrm{H}^{+}$ and $50 \mu \mathrm{M} \mathrm{Fe}^{3+}$.

and 1.25 ps with almost equal pre exponential factors of 0.46 and 0.42 and stimulated emission $140 \mathrm{fs}(23 \%)$ and $500 \mathrm{fs}(62 \%)$. On addition of protons the contributions from the excited states are shorter at $120 \mathrm{ps}$ and $1 \mathrm{ps}$ with pre exponential factors of 0.47 and 0.42 , respectively. In the presence of acid and oxidant the stimulated emission is mono ex ponential with an emission lifetime of $160 \mathrm{fs}$.

\section{Conclusions}

The successful operation of fluorescent logic gate $\mathbf{1}$ is another convincing illustration of the cross fertilization of fluorescent $\mathrm{pH}$ in dicators and fluorescent redox indicators [11]. Specifically, $\mathbf{1}$ in corporates a ferrocene naphthalimide piperazine format, which con sists of an electron donor, fluorophore and proton receptor/electron donor with PET and ICT mechanisms. Molecule 1 responds to an oxi dant and protons in accordance to two input AND logic by emitting a fluorescent signal in mixed aqueous methanol. Future engineering of systems responsive to $\mathrm{pH}$ and redox potential should continue to pro vide stimulating examples of information processing at the molecular level $[36,37]$ and practical application in various realms including cell biology [8] and corrosion detection [1].

\section{Acknowledgements}

This research was supported by the University of Malta, the Embassy of France to Malta, CNRS and the MCST. Prof. Robert M. Borg is thanked for assistance with the acquisition of the NMR spectra.

\section{References}

[1] Pourbaix M. Atlas of electrochemical equilibria in aqueous solutions. Oxford: Pergamon Press; 1966.

[2] Brookins DG. Eh-pH diagrams for geochemistry. Heidelberg: Springer Berlin; 1988.

[3] Burtis CA, Ashwood ER. Tietz fundamentals of clinic chemistry. fifth ed. Philadelphia: W. B. Saunders Company; 2001.

[4] Gellerman G. Lett Drug Des Discov 2016;13:47-63.

[5] de Silva AP, Moody TS, Wright GD. Fluorescent PET (Photoinduced Electron Transfer) sensors as potent analytical tools. Analyst 2009;134:2385-93.
[6] Yue Y, Huo F, Lee S, Yin C, Yoon J. A review: the trend of progress about pH probes in cell application in recent years. Analyst 2017;142:30-41.

[7] Magri DC. Photoinduced electron transfer as a design concept for luminescent redox indicators. Analyst 2015;140:7487-95. Analyst 2017;142:676.

[8] Johnson I, Spence MTZ. The molecular probes handbook: a guide to fluorescent probes and labeling technologies. eleventh ed. Life Technologies Corporation; 2010.

[9] Li LZ, Xu HN, Ranji M, Nioka S, Chance B. Mitochondrial redox imaging for cancer diagnostics and therapeutic studies. J Innov Opt Health Sci 2009;2:325-41.

[10] Magri DC, Johnson AD, Spiteri JC. Fluorescent photoinduced electron transfer (PET) logic gates for acidity $(\mathrm{pH})$ and redox potential (pE). J Fluoresc 2017;27:551-9.

[11] Magri DC. 'Pourbaix sensors': fluorescent molecular logic gates for $\mathrm{pE}$ and $\mathrm{pH}$ Supramol Chem 2017;20:741-7.

[12] Farrugia TJ, Magri DC. 'Pourbaix sensors': a new class of fluorescent pE-pH molecular AND logic gates based on photoinduced electron transfer. New J Chem 2013;37:148-51.

[13] Magri DC. A fluorescent AND logic gate driven by electrons and protons. New J Chem 2009;33:457-61.

[14] Magri DC, Camilleri Fava M, Mallia CJ. A sodium-enabled 'Pourbaix sensor': a three-input AND logic gate as a 'lab-on-a-molecule' for monitoring $\mathrm{Na}^{+}, \mathrm{pH}$ and $\mathrm{pE}$ Chem Commun 2014;50:1009-11.

[15] Spiteri JC, Schembri JS, Magri DC. A naphthalimide-based 'Pourbaix sensor': a redox and $\mathrm{pH}$ driven AND logic gate with photoinduced electron transfer and internal charge transfer mechanisms. New J Chem 2015;39:3349-52.

[16] Johnson AD, Paterson KA, Spiteri JC, Denisov SA, Jonusauskas G, Tron A, McClenaghan ND, Magri DC. Water-soluble naphthalimide-based 'Pourbaix sensors': $\mathrm{pH}$ and redox-activated fluorescent AND logic gates based on photoinduced electron transfer. New J Chem 2016;40:9917-22.

[17] Banerjee S, Veale EB, Phelan CM, Murphy SA, Tocci GM, Gillespie LJ, Frimannsson DO, Kelly JM, Gunnlaugsson T. Recent advances in the development of 1,8-naphthalimide based DNA targeting binders, anticancer and fluorescent cellular imaging agents. Chem Soc Rev 2013;42:1601-18.

[18] Panchenko PA, Fedorov YV, Fedorova OA, Jonusauskas G. FRET versus PET: ratiometric chemosensors assembled from naphthalimide dyes and crown ethers. Phys Chem Chem Phys 2015;17:22749-57.

[19] Liu S, Bai H, Sun Q, Zhang W, Qian J. Naphthalimide-based fluorescent photoinduced electron transfer sensors for saccharides. RSC Adv 2015;5:2837-43.

[20] Fu Y, Zhang J, Wang H, Chen J-L, Zhao P, Chen GR, He XP. Intracellular pH sensing and targeted imaging of lysosome by a galactosyl naphthalimide-piperazine probe. Dyes Pigments 2016;133:372-9.

[21] Georgiev NI, Dimitrova MD, Mavrova AT, Bojinov VB. Synthesis, fluorescencesensing and molecular logic of two water-soluble 1,8-naphthalimides. Spectrochim Acta: Mol and Biomol Spectrosc 2017;183:7-16.

[22] Li M, Ge H, Mirabello V, Arrowsmith RL, Kociok-Köhn G, Botchway SW, Zhu WH, Pascu SI, James TD. Lysosomal tracking with a cationic naphthalimide using multiphoton fluorescence lifetime imaging microscopy. Chem Commun 2017;53:11161-4.

[23] Chai X, Fu YX, James TD, Zhang J, He XP, Tian H. Photochromism and molecular logic gate operation of a water-compatible bis-glycosyl diarylethene. Chem Commun 2017;53:9494-7.

[24] Li M, Guo Z, Zhu W, Marken F, James TD. A redox-activated fluorescence switch based on a ferrocene-fluorophore-boronic ester conjugate. Chem Commun 2015;51:1293-6.

[25] Magri DC, Spiteri JC. Proof of principle of a three-input AND-INHIBIT-OR combinatorial logic gate array. Org Biomol Chem 2017;15:6706-9.

[26] Al-Kutubi H, Reza Zafarani H, Rassaei L, Mathwig K. Electrofluorochromic systems: molecules and materials exhibiting redox-switchable fluorescence. Eur Polym J 2016;83:478-98

[27] Chen S, Bian Q, Wang JP, Zheng XW, Lv L, Dang ZM, Wang GJ. Photo, pH and redox multi-responsive nanogels for drug delivery and fluorescence cell imaging. Polym Chem 2017;8:6150-7.

[28] Yan Y, Sun NW, Li FF, Jia XT, Wang C, Chao DM. Multiple stimuli-responsive fluorescence behavior of novel polyamic acid bearing oligoaniline, triphenylamine, and fluorene groups. ACS Appl Mater Interfaces 2017;9:6497-503.

[29] Meng TT, Xue LX, Wang H, Wang KZ, Haga M. pH controllable photocurrent switching and molecular half-subtracter calculations based on a monolayer composite film of a dinuclear Ru-II complex and graphene oxide. J Mater Chem C 2017;5:3390-6.

[30] Chen W, Zhong P, Meng F, Cheng R, Deng C, Feijen J, Zhong Z. Redox and pHresponsive degradable micelles for dually activated intracellular anticancer drug release. J Contr Release 2013;169:171-9.

[31] Magri DC, Callan JF, McClenaghan ND, de Silva AP, Fox DB, Samankumara Sandanayake KRAS. The anthracen-9-ylmethyloxy unit: an underperforming motif within the fluorescent PET (photoinduced electron transfer) sensing framework. J Fluoresc 2005;15:769-75.

[32] Dawson WR, Windsor MW. Fluorescence yields of aromatic compounds. J Phys Chem 1968;72:3251-60.

[33] Zheng S, Lynch PLM, Rice TE, Moody TS, Gunaratne HQN, de Silva AP. Structural 
effects on the pH-dependent fluorescence of naphthalenic derivatives and consequences for sensing/switching. Photochem Photobiol Sci 2012;11:1675-81.

[34] Scerri GJ, Cini M, Schembri JS, da Costa PF, Johnson AD, Magri DC. Redox-enabled, pH-disabled pyrazoline-ferrocene INHIBIT logic gates. ChemPhysChem 2017; 18:1742-5.

[35] Spiteri JC, Denisov SA, Jonusauskas G, Klejna S, Szaciłowski K, McClenaghan ND, Magri DC. Molecular engineering of logic gate types by module rearrangement in
'Pourbaix Sensors': the effect of excited-state electric fields. Org Biomol Chem 2018. http://dx.doi.org/10.1039/c8b00485d.

[36] de Silva AP. Molecular logic-based computation. Cambridge: The Royal Society of Chemistry; 2013.

[37] Erbas-Cakmak S, Gunnlaugsson T, Kolemen S, James TD, Sedgwick AC, Yoon J, Akkaya EU. Molecular logic gates: the past, present and future. Chem Soc Rev 2018;47:2228-48. 